\title{
REGULATORY MONITORING AND REGULATEE'S FIRM PERFORMANCE: AUDIT THEMATIC FINDING ON WATER OPERATOR PERFORMANCE IN MALAYSIAN WATER SERVICES INDUSTRY
}

\author{
Ir. Muhamad Sobri Bin Zakaria ${ }^{1}$ \\ Suruhanjaya Perkhidmatan Air Negara (SPAN), Malaysia. \\ (Email: sobri@span.gov.my) \\ Haslina Binti Hassan ${ }^{2}$ \\ Graduate School of Business, Universiti Kebangsaan Malaysia (UKM), Malaysia. \\ (Email: haslina.hassan@ siswa.ukm.edu.my) \\ Prof. Madya Dr Mohd Hizam bin Hanafiah ${ }^{3}$ \\ Faculty of Economics and Management, Universiti Kebangsaan Malaysia (UKM), Malaysia. \\ (Email: mhhh@ukm.edu.my)
}

Received date: $14-06-2019$

Revised date: $20-06-2019$

Accepted date: 11-07-2019

Published date: 12-09-2019

To cite this document: Zakaria, M. S., Hassan, H., \& Hanafiah, M. H. (2019). Regulatory Monitoring and Regulatee's Firm Performance: Audit Thematic Finding on Water Operator Performance in Malaysian Water Services Industry. Journal of Information System and Technology Management, 4(14), 34-46.

DOI: $10.35631 /$ jistm.414004

\begin{abstract}
Background: This study provides a report of the audit thematic findings on the regulatory role towards regulatee's firm performance. Based on the literature, audit activities is part of monitoring mechanism that can improve firm performance in the situation where a controlling power such as holding shares and executive power does exist. However, in the context of regulator and regulatee relationship in Malaysian water services industry, the regulator has an authority to control and monitor the regulatee's firm performance. The regulator has monitoring power stipulated by law, Water Services Industry Act 2006 (Act 655). In this scenario, the regulator does not hold any share in the regulatee's firm, neither hold executive power such as sitting as board of directors. Method: Conducting longitudinal thematic audit on water services providers (Regulatee /Auditee) and continuous monitoring activities. Sixteen study with five themes on thirteen water operators in Malaysia have been conducted to confirm on the finding. The audit execution holds by Water Industry Audit Division (Auditor), a regulator representative. Result: Consistent with the prior study and in line with the objective of the regulator establishment in ensuring the sustainability of water services industry, the report found several improvements in regulatee's firm performance that further improves national water services efficiency. Conclusion: This study extent the current dimension of a common auditor's role to regulatory audit activities as a monitoring mechanism that elaborates regulatory effectiveness towards regulatee's firm performance.
\end{abstract}


Keywords: Thematic Audit, Regulator, Licensee, Efficiency, Capacity

\section{Introduction}

The financial scandals and audit failures in early 21th century has alarmed the awareness of auditing matters. The appreciation towards auditing role indeed of fundamental reforms increases (Mark L.Defond; Jere R.Francis, 2005) as well as providing an opportunity of audit research. The demand for audit upsurges and becoming mandatory in complying and conforming to statutory requirement as part of firm financial declaration. Therefore, the audit quality and auditor integrity becoming critical issues as the numbers of fraud reported increases globally. Several factors associated with the successfulness of audit execution and the most importantly is the quality of audit. The audit quality contributed by audit tenure, auditor size, number of clients and financial health of the firm (Donald R.Deis, 1992).

Theoretically, an audit was introduced to verify the honesty of person and later the auditor's role directly linked to management's stewardship function. According to Mahdi (2011) many scholar defines auditing as "a systematic process of objectively obtaining and evaluating evidence regarding assertions about economic actions and events". The purpose of statutory audit is to provide an independent opinion pertaining to truth and fairness of the financial statements. According to Center for Audit Quality, an audit offers the assessment of the internal control effectiveness that can boost investor confidence.

In the perspective of thematic audit done in this research is focusing on the identified scope that potentially bring high risk to the sustainability of water services industry. The objective of thematic audit is to execute independent audit to water services provider on high impact activities that may disrupt the operation and delivery of water supplies. The transparent audit findings will be reported and distributed to the auditee, stakeholders and respective related Ministry.

The objective of this study is to highlight the relationship between regulatory monitoring activities and regulatee firm's performance. Secondly is to confirm the audit activities and findings is an appropriate tools for monitoring the regulatee firms performance reflected from effective governance by the regulator.

The performance of an organization is contributed by several factors whether it is from external or internal aspect. The revolution of appropriate business performance measures has been discussed extensively. The appropriate performance measurement by taking into a balanced measurement instrument encompasses of financial and non-financial perspective are needed especially in a dynamic change of current situation. Particularly, in cross-national and crosssectoral variation consisting of state, market, society and public-private governance arrangements.

In the context of regulated industry, regulator has the authority in imposing performance indicators to its regulatee(s). The empirical evidence from past studies identified the adoption of integrated performance as part of performance measurement concerning business-toconsumer and business-to-business oriented requires more holistic to subsist in a dynamic situation. However, there were limited study of integrated performance in regulated industries. Therefore, this study explore more on the adoption of integrated performance in regulated industry, water services industry in Malaysia. 
Although both entities, regulator and regulatee, are separated by ownership nor sitting on directorship but the regulator has fiduciary duty over the regulatees' activities. Water Services Industry Act 2006 (Act 655). The Agency Theory relationship between regulator whom act as principal and regulatee whom act as agents is extended from a common scenario of Agency Theory. Whereas, in a common scenario of Agency Theory, principal-agent relationship is between shareholder (principal) and management team (agent). It is a duty for the agent to perform on behalf of the principal. The common agency problem does exist in this unique scenario such as conflict of interest. Limited study has been done pertaining to Agency Theory in the context of regulator (principal) and regulatee (agents) especially in Malaysia.

This study involves discovering the lack of research in the context Agency Theory and integrated performance in regulated industry especially in Malaysia water services (including sewerage). This review would be able to answer the important of audit as part of monitoring mechanism in improving regulatees' firm performance. Previous effort and focus have been made based on technical issues such as water quality, water treatment and water facilities quality. In this context, several factors influence the effectiveness of this relationship requires further investigation. Thus this paper attempt to fill the gap between the effectiveness of regulator monitoring role towards the performance of regulatee using longitudinal study of audit activities.

This study is expected to contribute not only on managerial aspect but also on theoretical aspects. The finding codicil the previous studies contributions in the perspective of knowledge as well as the application approach for confirming principal's efficiency in respect of effective monitoring towards agent's performance. Thus, this research is expected to introduce a new model between principal-agent relationships in the perspective of regulator-regulatee relationship that can be generalized in other regulated industry particularly in Malaysian jurisdiction. Other than that, present paper takes a longitudinal approach to show how and why regulatory monitoring mechanism and public audit oversight may prelude to the strengthening of governance (Anna Alon, 2019).

\section{Literature Review}

\section{Agency Theory}

Hayes et al (2005) highlighted four theories of audit that are Policeman Theory, The Lending Credibility Theory, Theory of Inspired Confidence and Agency Theory. The most prominent and widely used audit theory is the Agency Theory that suggest the auditor is appointed in the interest of both parties as well as the management.

By definition, Agency Theory attempts to describe a relationship where one party (the principal) delegates work to another (the agent). The fundamental of Agency Theory principles the governance, delegation of contractual powers, central government controls and power of intervention and hierarchical authority relation (Etienne 2013). According to Eisenhardt (1989), Jensen and Meckling (1976) explain the interaction of Agency Theory between corporate governance and firm performance in the situation where there is a separation of the ownership and management (Ahmed Haji \& Mubaraq, 2015). Agency Theory also generally arise the auditor's role particularly in the resolution of conflict between external user's and management's use over financial statement information (Mahdi 2011).

In a common scenario of Agency Theory, principal-agent relationship is between shareholder 
and management team. The principal has control over the agent in the context of ownership structure whereby the principal is the owner (shareholder) of the company (Eisenhardt 1989). The agent has to perform on behalf of the principal as they were paid and bound by employment contract. It is agent role to ensure the goal of the principal is achieved. However, principal's obligation together with the effectiveness of the agent in performing their respective roles is important. Principal composition of knowledge capacities, human resource management effectiveness and decision-making style (Morais \& Kakabadse, 2013) will reduce corporate failure resulting from poor governance practices (Dalton et al.2010; Hampel 1998; Othman \& Rahman 2011; Yasser \& Mamun 2015). This finding supported by Bruton, Peng, \& Xu (2015) emphasizing on the efficiency management and agents should have clear understanding of their role and fiduciary duty would reflect to the overall performance. Besides that, the agents should also take seriously about implementing and maintaining best practices especially in a complex business environment.

However, in this study the relationship between agent and principal is extended to a regulated industry. Whereby, the regulator performs as a principal and the regulatee is an agent. In this unique situation, regulator who is a principal has a control power over the entities that under their supervision (the agents) even though both parties have separation of ownership structure. Similar to a common scenario of agent-principal relationship, there is a possibility that conflict between regulator and regulate might occurs as stated in literature (Etienne, 2013). For example, the objective and mission of each parties is uniquely designed for specific purposes (Metcalfe, 2000) and perform within each individual entity limited ability and resources. Such conflict seems to have impact to the performance of the agent and lead to disruption in achieving organization performance and objectives.

Regulator and regulatee often have divergence in goals and contributes to a difficult cooperation (Etienne 2013). In this situation, although the principal is a dominant entity, their views are not coordinated and will be interpreted negatively by the agent. Regulator in performing relationship with regulatees whether as legality relationship, authority relationship or solidarity relationship, the superior position role supported by legal rules and given a power to act as enforcement agent to federal government. The ambiguity of regulatory encounters from law, prosecution, or solidarity exist contributes to misunderstanding and action taken for any resolution that lead to effectiveness is hardly to achieve. Past study on highlighted that Regulatory Technology (RegTech) is the best solution for the compliance and effective regulatory (Johansson, 2019), especially in auditing field, accounting and tax regulation.

Other than that, prior literature also identified that strategic leadership competencies (Norzailan, Yusof, \& Othman, 2016)(Zumalia Norzailan Shazlinda Md Yusof \& Rozhan Othman 2016), knowledge management capacity (Chen \& Huang, 2009) and right decision has the significant impact on internal management efficiency that not only apply to the principal but also to the agent, as both parties has impact to the overall industry performance.

Suruhanjaya Perkhidmatan Air Negara (SPAN) Act 2006 (Act 654) provide the function of a regulator (The Commission). One of the role is advising the Minister (Government of Malaysia, Suruhanjaya Perkhidmatan Air Negara Act 2006 (Act 654), 2006) in relation to water supply and sewerage services such as enforcing Water Services Industry Act 2006 (Act 655). This is to provide an effective management of water and sewerage services and ensuring the productivity of the water supply and sewerage services and the monitoring of operator compliance to meet stipulated standard, obligation, relevant laws and guidelines. Besides that, The Commission would also have to increase their effort towards improving the efficiency in 
terms of national policy, national development goal and ensure long-term sustainability of the industry, and protecting investor as well as consumer.

In addition, Section 4 (1) Act 655 requires a person to hold individual license if he own a public water supply of sewerage system or any part of the system, or undertake, provide or make available any water supply services or sewerage services or any part of the services (Government of Malaysia, Water Service Industry Act 2006 (Act 655), 2006). This requires all selected water operators to hold an individual license and to perform its duties and obligations. Based on the provision in Act 655, Section 29(5) provides The Commission or its authorized officers or agents at any time, as it deems necessary, conduct an audit on the business and activities of the licensee. In line with previous study, under the institutionalized agency perspective, auditor is viewed as an agent with authority delegated from the principal (Fabio La Rosa, 2019).

\section{Audit Quality}

Auditing is a formal, systematic and disciplines approach designed to evaluate and improve the effectiveness of processes about related areas. Auditing is governed by professional standard and completed by an individual whom a certified auditor which is independent of the process being audited. An independent, expertise, authority, resource and diligence are the component of committee effectiveness that contributed to audit quality (DeZoort, R.Hermanson, S.Archambeault, \& A.Reed, 2002). In the perspective of this study, the auditor are the representative from regulator that carries authority capacity and performs as independent in the context of finding and reporting.

In a public sector audit perspective, the role of audit inclusive of both internal and external auditing. The public sector auditor's role support the governance responsibilities and part of determinant in good governance practices (Richard Fairchild, 2019) that addresses oversight and insight accountabilities (The Institute of Internal Auditors, 2012). Auditors' use financial audit, performance audits, investigation and advisory service as a tools or mechanism in executing the task. A formal mandate from the authorities given the audit activity's power and duties through constitution, charter or other basic legal document. Hereafter, an audit could be conducted with complete and unrestricted access to the system, documents and record, property as appropriate for the performance of audit activities.

The Regulator through auditor has to be independent in performing their role, in line with the principle underpinning in Malaysian Code of Corporate Governance. This study confined the auditor is independent in performing their obligations. This practice is in line with law enacted to the Regulator who has fiduciary duty regulating the industry.

The composition of the audit members encompasses of technical and non-technical expertise with various experience audit field including at public and private company. Members of audit team are selected based on their individual skill with in-depth knowledge to match with each particular audit scope.

\section{Method}

\section{Audit Scope}

The finding of present study based on a longitudinal audit execution and continuous monitoring that showing how audit oversight may improve service performance and enhance the efficiency 
(Anna Alon, 2019). Aiming for a holistic audit execution, the findings covers various perspectives. The scope of audit thematic concentrating on both technical and non-technical aspects within the authorized auditee(s) services. This paper defined the authorized scope of auditee as stipulated in their respective services license that has been approved by The Ministry of Water, Land and Natural Resources (formerly by The Ministry of Energy, Green Technology and Water). Audit scope for technical aspects encompasses non-revenue water (NRW) management, water demand, water supply planning, asset management and capital expenditure (CAPEX) project implementation. While, the audit scope for non-technical aspects involve financial and consumer affairs such as collection efficiency, billing efficiency, customer complaint, operating ratio and key performance indicator achievement. These audit themes are chosen based on high affect and risk level to the performance of water services industry.

The chosen themes are also based on the criticality of the issue(s) faced by the industry. If the issue(s) remain unattended for a long period, the service performance potentially affected and end consumer might have water supply and sewerage services interruption. Thus would bring difficulties to the domestic consumer in running day-to-day activities, and potentially million lost to commercial consumer due to glitch in producing their product and interruption of the product supply. As water is necessity and sewerage is a primary services, it would bring national image at global as foreign investor and tourism industry is concerned.

\section{Audit Implementation}

A comprehensive audit execution is shown in Figure 1, it elaborates an audit thematic has high data integrity and reliability for the purpose of strategic planning and decision making at various level, including policy maker amongst inter-agency. The issues highlighted in the audit reports includes the performance index that indicates the highest potential risk faced by water provider company.

The implementation of audit comprises of interview session, document and system review and physical visit to the selected plant. The process then followed by monitoring process is continuously to ensure the findings and recommendation are attended. This is to ensure that business risk and compliance are being identified and addressed accordingly. Wallace (1980 and 1987) suggested that monitoring action in the context of Agency Theory is suitable where the delegating decision-making power to one party. In this situation, the agent is motivated to agree to be monitored and expecting benefits from such activities. This monitoring hypothesis is applicable to any organization including different levels of management in companies as well as government. The monitoring activities can benefits from each other such as identifying risks, reduce audit duration and frequency, and focus more audit efforts in other areas.

A normal audit thematic process inclusive of conclusive finding, it is a comprehensive reports on the performance assessment, auditee performance achievement. The auditees' key performance is analysed based on specific performance indicators set by regulator. Auditor identifies the issue(s) pertaining to technical, economic, enforcement, customer service, staff competencies and capital expenditure, as well as project specification, plan and progress. The issue(s) identified not only for auditee's action but also associated to the regulator and policy maker. The audit report also provides recommendation(s) and necessary action as part of advisory service.

This is to ensure the respective parties play their role and obligation effectively and efficiently. A collective coordination, decision and efforts are highly contributes to the national water 
service delivery and hence uplift the industry to global standard not only on service level, but also on technology and innovation aspect. The report is distributed in two version, which are open, and limited edition. The open edition is distributed to the auditee, stakeholders as well as to The Ministry.



Figure 1 Audit Thematic Phase Overview

\section{Research Model}

A longitudinal period of five (5) years audit execution representing long observations by the auditor leads to a comprehensive finding. Started in year 2014 until June 2018, fourteen (14) researches had been conducted focusing on six (6) audit themes; Non-Revenue Water (NRW) Management, Supply Planning and Water Demand, CAPEX Implementation, Asset Management, and Collection and Billing Efficiency. The themes covering both technical and non-technical aspect to ensure a holistic audit finding is achieved. Thirteen (13) water services operators, one (1) from sewerage services operator and facility fund provider respectively. Each research took approximately 3-4 months to complete depending on the criticality of the finding. The audit timeframe starting from the audit - opening meeting until the final report is issued.

\section{Result}

\section{Audit Findings}

A total of one hundred and eighty-six (186) findings identified through-out the years. Hundred thirty-six issues were resolved while the remaining issues requires a collaborative action and decision amongst policy makers and decision maker of inter-agency in Federal Government. The audit findings are summarized in Table 1 below:

Table 1: Summary of Audit Findings on Respective Themes

\begin{tabular}{|l|rl|}
\hline \multicolumn{1}{|c|}{ Audit Themes } & \multicolumn{1}{c|}{ Audit Findings } \\
\hline $\begin{array}{l}\text { 1. } \\
\text { Planning And Water } \\
\text { Demand } \\
\text { Effectiveness }\end{array}$ & i. & Inaccurate reporting on plant capacity \\
& ii. & Overloading; 30 \% plants are operating over designed \\
& capacity
\end{tabular}




\begin{tabular}{|c|c|}
\hline Audit Themes & Audit Findings \\
\hline & $\begin{array}{l}\text { iv. Inefficient NRW asset management } \\
\text { v. Lack of DMA monitoring }\end{array}$ \\
\hline $\begin{array}{l}\text { 3. } \text { CAPEX } \\
\text { Management }\end{array}$ & $\begin{aligned} & \text { i. } \text { Poor planning pertaining land/site procurement } \\
& \text { ii. Impractical designed and low competency of consultant } \\
& \text { selection } \\
& \text { iii. Late progress and low supervision / management in } \\
& \text { project implementation }\end{aligned}$ \\
\hline 4. Billing Management & $\begin{array}{l}\text { i. Inefficient billing; system integration incomplete } \\
\text { ii. Data reporting misleading } \\
\text { iii. Weak Enforcement on outstanding bill }\end{array}$ \\
\hline 5. Asset Management & $\begin{array}{l}\text { i. Asset management system development towards ISO } \\
\text { 550001:2014 certification } \\
\text { ii. Efficient sectorial risk management } \\
\text { iii. Partial asset management due to weak financial } \\
\text { availability }\end{array}$ \\
\hline $\begin{array}{l}\text { 6. Key Performance } \\
\text { Indicator }\end{array}$ & $\begin{aligned} \text { i. } & \text { Absent of base year performance } \\
\text { ii. } & \text { Target KPI lower than previous achievement } \\
\text { iii. } & \text { No impact on unachieved KPI. }\end{aligned}$ \\
\hline
\end{tabular}

\section{Positive Impact on Audit Finding and Continuous Monitoring}

With continuous effort done by the auditee(s) and close monitoring by regulator, auditor found that several improvements in service delivery reflected by auditee performance achievement (Suruhanjaya Perkhidmatan Air Negara, 2017). Regulator has set performance index for the auditee(s) to plan their necessary action in achieving the targets. The standard performance index across the sector is set to ensure the auditee(s) are moving towards the national water industry mission. The prominent key performance indicator (KPI) covers technical and nontechnical aspects. For technical aspects the regulator concern on non-revenue water (NRW) rate, percentage of population served, reserve margin, consumption per capita per day as well as water quality. While for non-technical aspect covers economics and consumer affairs.

Continuous monitoring over the years has identified that the necessary action on the audit findings, Table 2. Several improvements in respective audit themes has been identified and positive impact not only to auditee but also to the industry as a whole. Auditors identified that necessary actions has been done and positive impact to the overall industry's performance:

Consistent with the audit finding and monitoring reports, Malaysia Water Industry Guide 2017 also reported significant improvement in several performance indicators (Suruhanjaya Perkhidmatan Air Negara, 2017). Not only improvement in technical aspect, the non-technical aspect also contributed to overall industry's performance achievement. National NRW recorded $35.5 \%$ in year 2015 has reduced to $35.2 \%$ in year 2016. However, for comparative and benchmarking of NRW across the states, Infrastructure Leakage Index (ILI) is the best indicator that has been used internationally. Water Loss Task Force (WLTF) introduced ILI and audit thematic applies this method in executing the audit thematic as benchmarking mechanism amongst water operators in Malaysia.

Population served in rural area has increased by $0.5 \%(93.0 \%-2015 ; 93.5 \%-2016)$ thus led to national population served increased by $0.2 \%$ across the state $(95.5 \%-2015 ; 95.7 \%-2016)$. While, the urban population served remain unchanged at $97.2 \%$ within the said period. Small improvement recorded contributed in Kelantan from 64.0\% (2015) to 64.7\% (2016), which 
significant increase in rural area by $1.3 \%(64.0 \%-2015 ; 67.7 \%-2016)$, and $0.2 \%$ in urban area $(61.5 \%-2015 ; 61.7 \%-2016)$.

Table 2: Positive Impact on Audit Thematic Findings and Recommendations

\begin{tabular}{|c|c|}
\hline Audit Themes & Improvement \\
\hline $\begin{array}{l}\text { 1. Planning and Water } \\
\text { Demand } \\
\text { Effectiveness }\end{array}$ & \begin{tabular}{|ll} 
i. & Increase water pressure in remote / critical area \\
ii. & Budget allocation from RMK and PAAB CAPEX \\
& financing \\
iii. & Realistic projection of demand and supply \\
iv. & Raw water resources study by State Regulatory Bodies
\end{tabular} \\
\hline 2. NRW Management & $\begin{aligned} & \text { i. } \text { NRW project implementation focusing on physical and } \\
& \text { commercial losses based on specific approach } \\
& \text { ii. } \text { Increase competencies program on NRW reduction } \\
& \text { iii. } \text { Installation of SIV meter as baseline indicator }\end{aligned}$ \\
\hline $\begin{array}{l}\text { 3. } \text { CAPEX } \\
\text { Management }\end{array}$ & $\begin{array}{ll}\text { i. } & \text { Reducing numbers of land transfer outstanding issues and } \\
\text { organised procedures } \\
\text { ii. } & \text { Periodic Coordination Meeting as monitoring mechanism } \\
\text { iii. } & \text { Physical and financial performance review }\end{array}$ \\
\hline 4. Billing Management & $\begin{array}{cl}\text { i. } & \text { Increase accuracy in revenue collection reporting } \\
\text { ii. } & \text { Improvement in billing system efficiency } \\
\text { iii. } & \text { Better enforcement enhancement. }\end{array}$ \\
\hline 5. Asset Management & $\begin{array}{l}\text { i. } \text { Critical asset identification for implementation priority } \\
\text { ii. Setting better procurement policy and procedure }\end{array}$ \\
\hline $\begin{array}{l}\text { 6. Key Performance } \\
\text { Indicator }\end{array}$ & $\begin{array}{cl}\text { i. } & \text { Improve accuracy for baseline achievement } \\
\text { ii. } & \text { Review target periodically } \\
\text { iii. } & \text { SMART basis performance target }\end{array}$ \\
\hline
\end{tabular}

Based on auditee(s) data, the unscheduled water services interruptions has shown significant reduction number of consumer complaints. Kedah recorded the 954 reduction of complaints from 5,325 (2015) to 4,934 (2016), followed by a reduction number of customer complaints also recorded at Johor reducing to 391 complaints from 5,952 (2015) to 4,998 (2016), and in Kelantan the numbers dropped by 48 complaints from 320 (2015) to 272 (2016).

Regulator long term strategic planning able to increase design capacity from 15,449 MLD (2006) to 19,056 MLD (2016) hence increase in production capacity from 12,296 MLD (2006) to 16,536 MLD (2016). Such development and improvement made within the years has bring significant impact to overall industry performance. Other than that, total revenue for water industry has increased from RM5,411,638 in 2015 to RM5,690,401 in year 2016.

Better achievement discussed above has led to significant improvement on consumer complaint. The highest number of complaints is pertaining to pipe burst/breakages/leak category has reduced from $41.2 \%$ in 2015 to $40.2 \%$ in 2016. For billing and meters category, the complaints dropped from $12.4 \%$ to $11.6 \%$, water pressure category complaints dropped from $6.7 \%$ in 2015 to $6.5 \%$ in 2016 and water quality complaints has reduced from $1.1 \%$ in 2015 to $0.9 \%$ in 2016.

Through strategic planning and holistic improvement plan at regulator level, the performance achievement of the auditee(s) particularly in respective scope of audit thematic has shown an 
improvement over the years. Positive impact to industry performance index attributed from efficient management at regulator and regulatee level has shown significant impact in service delivery and industry sustainability. Table 3 below summarized the industry's performance trend from year 2015 to year 2017 for performance indicator related to audit themes.

Table 3: National Water Services Industry Performance Trend

\begin{tabular}{|l|c|c|c|}
\hline Key Performance Indicator & $\mathbf{2 0 1 5}$ & $\mathbf{2 0 1 6}$ & $\mathbf{2 0 1 7}$ \\
\hline NRW (\%) & 35.5 & 35.2 & 35.3 \\
\hline Reserve Margin (\%) & 14.2 & 13.7 & 14.3 \\
\hline Design Capacity (MLD) & 18,835 & 19,296 & 19,706 \\
\hline Population Served (\%) & 95.5 & 95.3 & 95.5 \\
\hline Water Services complaints (nos) & $1,056,837$ & $1,085,220$ & $1,023,719$ \\
\hline Water Revenue (RM Million) & 5,412 & 5,954 & 5,875 \\
\hline
\end{tabular}

The finding also identified that there was an outstanding issues. These issues were beyond the auditee and regulator resort capacity, which among others are pertaining to policy and directive from Federal Government that requires collective decisions from inter-agency. Conflict of interest creates dispute within State Government who is a parent company of the auditee against Federal Government, water tariff revision exercise was identified as one of the issues amongst others. State Government preference is to keep water tariff low to ensure poor category consumer able to get the water supply. While Federal Government intent to increase water tariff rate to reduce the subsidy that would be transferable for building better facility.

Other than that, water restructuring related issue such as take over, mergers and acquisition and corporatized process of State Department of Water Supply (Jabatan Bekalan Air Negeri) was another issue that requires a collective effort. Also, the issue on financial assistance pertaining to converting loan to grant for upgrading, refurbish and construction of facilities. A long negotiation process would lead to financial distress and inaccurate planning to the auditee.

Besides that, it also brings down the service level performance of auditee and water services industry as a whole. To overcome the issues discussed above, a join audit would also be considered amongst inter-agency for collaboration action that able to produce a comprehensive and holistic report.

\section{Discussion and Conclusion}

In the context of Malaysian Water Services Industry, this study found that no research has been done in relation to audit execution that confirms regulator-regulatee relationship and the effectiveness of regulatory impact to the regulatee performance. This study identified several contributions to the perspective of knowledge as well as the application approach for investigating the principal monitoring mechanism and the effect towards agent performance.

First, previous researches have investigated Agency Theory in the context of shareholder as principal and management team as agent. In this study, the relationship is extended to regulator whom perform as principal and regulatee whom perform as an agent. Therefore, this study, will add-on finding from previous studies to the Agency Theory in the context of regulatorregulatee relationship.

Secondly, the finding from this study enhance the understanding of regulator and regulatee reciprocal impact concerning the efficiency and performance of both parties. It is anticipated 
that regulator audit oversight as part of monitoring mechanism brings better firm(s) performance of the regulatee. Thus, this research introduces a new model between principalagent relationships in the perspective of regulator-regulatee relationship that can be generalized in other regulated industry particularly in Malaysian jurisdiction.

Thirdly, this research may contribute to the current knowledge of relationship between regulator monitoring mechanism and regulatee firm performance. It offers prediction of regulatee firm performance that have potential impact to the water services industry. It would also an annotation to the regulator for better strategic planning and regulate the industry more efficient in future. This research provides an empirical evidence to support both regulator and regulatee have relationship in the perspective of reciprocal impact.

Fourthly, this study represent a longitudinal research that offers better understanding the causal relationship between antecedents. Therefore, we suggested that regulatory monitoring mechanism influence the regulatee firm performance, and the audit thematic finding has proven that there is significant relationship between both parties.

Fifth, research shown that the audit opinion may provide useful information in user's decisionmaking especially the regulator and agencies under Federal Government. Other than that, the continuous monitoring would enhance the understanding of laws and regulation specifically pertaining to Act 655, besides re-educate staff on regulation and issues identified in the audit amongst auditee. This would further enable the regulator to identified loopholes, establish necessary policies, and make right decision in day-to-day activities.

Despite of its contribution, the current study should be interpreted with certain limitations. First, it used cross-sectional research design in which the audit execution(s) were based on dissimilar period amongst auditee(s). As such, it does not permit us to view the findings as conclusive. Future research should exercise longitudinal design within the timeframe for the uniformity amongst auditee(s).

Secondly, the audit finding only reported on the status of performance achievement of the auditee(s). For future research, we propose to extent the audit finding for risk assessment and further risk management for more constructive results. We believe it would bring better result of auditee(s) performance and fruitful input to policy maker for actions that are more inclusive. Thirdly, present audit execution is reported to respective agency only. Therefore, the audit findings that relates to inter-agency issues(s) within the policy maker remain unsolved. Auditor suggested that, the report should be extended to General Auditor of Malaysia (Jabatan Audit Negara) and respective Ministry for collaborative effort in managing the issue(s).

However, despite the limitations of the present research, we addresses the important of audit execution to confirm the relationship between efficiency of the regulatory monitoring mechanism and regulatee(s) firm performance. The finding demonstrated that an efficiency of regulatory function and continuous monitoring drives a better performance amongst water services operator in Malaysia. Thus enhance towards achieving a global baseline status of targets and indicators of Sustainable Development Goal 6 on Water and Sanitation 2018 (United Nations 2018). 


\section{References}

Ahmed Haji, A., \& Mubaraq, S. (2015). The Implications Of The Revised Code Of Corporate Governance On Firm Performance A Longitudinal Examination Of Malaysian Listed Companies. Journal of Accounting in Emerging Economies, 350-380.

Anna Alon, A. M.-T. (2019). Dynamics and Limits of Regulatory Privatisation: Reorganizing audit oversigth in Rusia. Special Issue on Government and the Governance of Business Conduct, 1-23.

Bruton, G. D., Peng, M. W., \& Xu, K. (2015). State-Owned Enterprises Around The World As Hybrid Organizations. The Academy of Management Perspectives, 92-114.

Chen, C.-J., \& Huang, J.-W. (2009). Strategic Human Resource Practices And Innovation Performance - The Mediating Role Of Knowledge Management Capacity. Journal of Business Research, 104-114.

Dalton, D. R., Ellstrand, A. E., Johnson, J. L., Daily, M., \& Dalton, D. A. (2010). Reviews Of Board Meta-Analytic Leadership Composition, Structure, And Performance Financial. Managerial and Decision Economics, 249-261.

DeZoort, E., R.Hermanson, D., S.Archambeault, D., \& A.Reed, S. (2002). Audit Committee Effectiveness: A Synthesis of the Empirical Audit Literatur. Journal Of Accounting Literature, Vol.21, pp.38-75.

Donald R.Deis, G. A. (1992). Determinants of Audit Quality. The Accounting Review, pp 462 - 479, vol 67.No.3.

Eisenhardt, M. (1989). Agency Theory: An Assessment and Review. Academy of Management Review, 57-74.

Etienne, J. (2013). Ambiguity And Relational Signals In Regulator-Regulatee Relationships. Regulation and Governance, 30-47.

Fabio La Rosa, C. C. (2019). Corporate Governance Of Audit Firms: Assessing the usefulness. Corporate Governance International Review, wileyonlinelibrary.com/journal/corg, 1432.

Government of Malaysia. (2006). Suruhanjaya Perkhidmatan Air Negara Act 2006 (Act 654). Malaysia: Percetakan Nasional Berhad.

Government of Malaysia. (2006). Water Service Industry Act 2006 (Act 655). Malaysia: Percetakan Nasional Malaysia Berhad.

Hampel, R. (1998). Committee On Corporate Governance. 1998: Gee Publishing Ltd.

Johansson, E. S. (2019). Regtech- A Necessary Tool To Keep Up With Compliance And Regulatory Changes? ACRN Oxford Journal of Finance and Risk Perspectives, Special Issue Digital Accounting, 71-85.

Mark L.Defond; Jere R.Francis. (2005). Audit Research after Sarbanes-Oxley. Auditing: A Journal of Practice \& Theory, pp.5-30, Vol.24.

Metcalfe, L. (2000). Reforming the Commission. Communities, 1-70.

Morais, F., \& Kakabadse, N. K. (2013). Delving into the Boardroom " Black Box " : A Research Model of " Board Learning Capability " (BLC). Open Journal of Business and Management, 76-90.

Norzailan, Z., Yusof, S. M., \& Othman, R. (2016). Developing Strategic Leadership Competencies. ournal of Advanced Management Science, 66-71.

Othman, Z., \& Rahman, R. A. (2011). Creating Value Governance : What it ought to be. African Journal of Business Management, 6972-6980.

Richard Fairchild, D. G. (2019). Audit Within the Corporate Governance Paradigm: A Cornerstone Built on Shifting Sand? British Journal of Management, Vol. 30, 90-105.

Salehi, M. (23 September, 2011). Audit Expectation Gap: Concept, Nature And Trace. African Journal of Business Management Vol. 5(21), 8376-8392. 
Suruhanjaya Perkhidmatan Air Negara. (2014). Laporan Audit Tematik Kajian Keberkesanan Pelaksanaan NRW Negeri Pahang (Pengurusan Air Pahang Berhad). Malaysia: Suruhanjaya Perkhidmatan Air Negara.

Suruhanjaya Perkhidmatan Air Negara. (2014). Laporan Audit Tematik Kajian Keberkesanan Perancangan Bekalan dan Permintaan Air Negeri Kedah (Syarikat Air Darul Aman). Malaysia: Suruhanjaya Perkhidmatan Air Negara.

Suruhanjaya Perkhidmatan Air Negara. (2015). Kajian Audit Tematik Kajian Air Tidak Terhasil (NRW) Negeri Perlis (Syarikat Air Perlis). Malaysia: Suruhanjaya Perkhidmatan Air Negara.

Suruhanjaya Perkhidmatan Air Negara. (2015). Laporan Audit Tematik Kajian Keberksanan Pelaksanaan CAPEX (Pengurusan Aset Air Berhad). Malaysia: Suruhanjaya Perkhidmatan Air Negara.

Suruhanjaya Perkhidmatan Air Negara. (2015). Laporan Audit Tematik Kajian Pengurusan Pengebilan Air Kelantan Sdn Bhd (AKSB). Malaysia: Suruhanjaya Perkhidmatan Air Negara.

Suruhanjaya Perkhidmatan Air Negara. (2016). Laporan Audit Tematik Kajian Keberkesanan Perancangan Bekalan dan Permintaan Air Serta Semakan KPI Kesinambungan Bekalan Air dan Tekanan Air Ke Atas Air Kelantan Sdn Bhd (AKSB). Malaysia: Suruhanjaya Perkhidmatan Air Negara.

Suruhanjaya Perkhidmatan Air Negara. (2016). Laporan Audit Tematik Kajian Pengurusan Pengebilan Ke Atas Indah Water Konsortium Sdn Bhd (IWK) 2016. Malaysia: Suruhanjaya Perkhidmatan Air Negara.

Suruhanjaya Perkhidmatan Air Negara. (2017). Laporan Audit Tematik Kajian Keberkesanan Pelaksanaan Air Tidak Terhasil (NRW) Ke Atas PBAPP Tahun 2017. Malaysia: Suruhanjaya Perkhidmatan Air Negara.

Suruhanjaya Perkhidmatan Air Negara. (2017). Laporan Audit Tematik Kajian Keberkesanan Pengurusan Projek Major Di Bawah Program Perbelanjaan Modal (CAPEX) di Pengurusan Aset Air Berhad (PAAB) 2017. Malaysia: Suruhanjaya Perkhidmatan Air Negara.

Suruhanjaya Perkhidmatan Air Negara. (2017). Laporan Audit Tematik Kajian Keberkesanan Perancangan Bekalan dan Permintaan Air Ke Atas SAJ Rahill (SAJR) 2017. Malaysia: Suruhanjaya Perkhidmatan Air Negara.

Suruhanjaya Perkhidmatan Air Negara. (2017). Malaysia Water Industry Guide 2017. Malaysia: Malaysian Water Association.

Suruhanjaya Perkhidmatan Air Negara. (2018). Laporan Audit Tematik Kajian Keberkesanan Pengurusan Aset Indah Water Konsortium Sdn Bhd (IWK). Malaysia: Suruhanjaya Perkhidmatan Air Negara.

The Institute of Internal Auditors. (2012). The Role Of Auditing in Public Sector Governance. USA: The Institute of Internal Auditors.

United Nations. 2018. Sustainable Development Goal 6 Synthesis Report 2018 on Water and Sanitation.

Yasser, Q. R., \& Mamun, A. A. (2015). The Impact Of CEO Duality Attributes On Earnings Management In The East. Corporate Governance: The international journal of business in society, 706-718.

Zumalia Norzailan, Shazlinda Md Yusof \& Rozhan Othman. 2016. Developing strategic leadership competencies. Journal of Advanced Management Science, 4(1), 66-71. 